\title{
Implementing ACCM Critical Care Guidelines for Septic Shock Management in a Cuban Pediatric Intensive Care Unit
}

\author{
José M. Cartaya MD MS, Luis E. Rovira MD MS, Yamilet Segredo MD MS, Idalys Álvarez MD, Yoandra Acevedo MD, \\ Ariel Moya MD MS
}

\begin{abstract}
INTRODUCTION Sepsis is the most common direct cause of death worldwide and septic shock the syndrome's most serious complication. In 2002, the pediatric intensive care unit of the José Luis Miranda Pediatric University Hospital in Santa Clara (Villa Clara Province), Cuba, began implementing the recently published guidelines of the American College of Critical Care Medicine (ACCM) for management of pediatric and neonatal septic shock, observing a drop in case fatality from $34.6 \%$ to $19 \%$ between the years 2003 and 2007 . ACCM updated these Guidelines in 2007.
\end{abstract}

OBJECTIVE Describe experiences with the use of the 2007 ACCM updated Guidelines and discuss their possible impact in reducing case fatality.

METHODS Between 2008 and 2010, a study was conducted of 280 children and adolescents, from newborns through 18 years, admitted to the pediatric intensive care unit with a diagnosis of septic shock. The diagnostic and therapeutic criteria used were those recommended in the ACCM's 2007 updated Guidelines. The dependent variable was case fatality. Independent variables were age, sex, comorbidity or prior chronic disease, origin and course of sepsis, hemodynamic state, blood glucose level, hyperglycemia, organ dysfunction, volume of fluid therapy administered, use of mechanical ventilation and therapeutic response.

RESULTS In the 3-year period, 28-day case fatality was $11.1 \%$ $(31 / 280)$. A total of 45 patients had comorbidities, with 14 deaths and

\section{INTRODUCTION}

Sepsis is the most common direct cause of death worldwide, and thus is considered a significant health problem, equally affecting children and adults.[1,2] It is a clinical syndrome caused by physiological changes indicating systemic inflammation from suspected or proven infection. Septic shock is the progression of these changes to the point where they compromise delivery of oxygen and metabolic substrates to the tissues.[3]

Several research teams are applying genetics and gene biology to reproductive cells as a way of developing new therapeutic strategies, seeking to identify sepsis markers and subclasses of septic shock. Diverse polymorphic genes extensively involved in inflammation, immunity and coagulation have been linked with susceptibility to sepsis.[4-7]

Pediatric septic shock is currently defined as sepsis accompanied by cardiovascular dysfunction, with or without hypotension,[8] recognizable before it occurs by a clinical triad of hypo- or hyperthermia, altered mental state, and peripheral vasodilation (warm shock) or cold extremities (cold shock).[9]

Globally, some 29,000 children aged $<5$ years die of sepsis daily. [10] In the USA, severe sepsis and septic shock are responsible for about 4500 deaths each year and almost US $\$ 2$ billion annually in medical expenditures.[11] A study published in 2001 put US case fatality at $34.1 \%$.[12] a case fatality rate of $31.1 \%$ vs. $7.2 \%(17 / 235)$ in previously healthy patients. Cold shock with a hemodynamic state of low cardiac output and high systemic vascular resistance predominated (68.9\%), with low cardiac output and low systemic vascular resistance the least common type (12.5\%), but the one with highest case fatality $(34.4 \%)$. Hyperglycemia was present in $39.6 \%$ of patients, with $15.3 \%$ case fatality; case fatality was higher $(25.6 \%)$ when hyperglycemia was in the $10-15.9 \mathrm{mmol} / \mathrm{L}$ range.

Fluid therapy of $40-100 \mathrm{~mL} / \mathrm{kg}$ was administered in the first hour to $90 \%$ of patients, increasing to $>96 \%$ in the first $3-6$ hours. The most common therapeutic response was fluid refractory, dobutamine responsive $(39.3 \%)$. Mechanical ventilation was used in $33.9 \%$ of patients, with a case fatality of $30.5 \%$. Cardiovascular, respiratory and hematologic dysfunctions were common. Failure of $\geq 4$ organs raised case fatality to $77.8 \%$.

CONCLUSIONS Implementation of ACCM Guidelines facilitates timely, appropriate care for septic shock patients and contributes to lower case fatality. Early aggressive fluid therapy with support of vasoactive drugs, either singly or in combination, has a positive impact on patient outcomes. Similar studies with a larger number of patients are needed to corroborate these conclusions.

KEYWORDS Pediatric intensive care units, sepsis, septic shock, circulatory collapse, organ dysfunction, organ failure, case fatality rate, practice guidelines, fluid therapy, Cuba

In 2002, the American College of Critical Care Medicine (ACCM) published Clinical Guidelines for Hemodynamic Support of Neonates and Children in Septic Shock, aiming to reduce case fatality.[9] The Guidelines prescribe measures for early recognition of septic shock and goal-directed therapies to optimize patient management during the first hour, including aggressive fluid resuscitation, insulin therapy to maintain normal glucose levels, steroids for patients at risk of absolute adrenal insufficiency, lung-protective ventilation in cases of acute respiratory distress syndrome, and dialysis if needed. Centers using the Guidelines report case fatality rates of $8-13 \%(1-3 \%$ in previously healthy children and $7-10 \%$ in chronically ill children). $[13,14]$

A 2001-2006 report found $14.6 \%$ case fatality in 178 sepsis patients in the pediatric intensive care unit (PICU) of the Luis Díaz Soto Military Hospital in Havana, and $53.8 \%$ case fatality for septic shock;[15] while in the PICU of José Luis Miranda University Pediatric Hospital (HPU, the Spanish acronym) in Santa Clara, Villa Clara Province, septic shock case fatality was $26.3 \%$ (unpublished hospital data).

In 2002, case fatality from septic shock in HPU PICU was $35.2 \%$. HPU began implementing the ACCM Guidelines in the last quarter of that year, observing a reduction in case fatality from $34.6 \%$ to $19 \%$ between 2003 and 2007 (unpublished data). The purpose of this 2008-2010 study is to describe implementation of the updated ACCM Guidelines[16] and discuss their possible impact on case fatality. 


\section{METHODS}

Type of study and patients A descriptive study was conducted from January 2008 through December 2010. Subjects were 280 male and female patients, newborn through 18 years, admitted to HPU's PICU with a diagnosis of septic shock. HPU, the referral hospital for Cuba's central provinces, has 321 beds, 10 in PICU, and provides care in 18 clinical and 8 surgical pediatric specialties.

\section{Diagnostic and therapeutic criteria}

Diagnostic The study used criteria described in the ACCM Guidelines of June 2002,[9] updated in 2007.[16] It also took into account the findings of the 2001 International Sepsis Consensus Conference,[17] its diagnostic criteria adapted for sepsis in children; and those of the 2005 International Pediatric Sepsis Consensus Conference, which defined sepsis and organ dysfunction-[18]definitions that help differentiate the clinical phases of sepsis, fundamentally between severe sepsis and septic shock.

Therapy Fluid replacement therapy was initially administered through one or two peripheral veins, or via intraosseous infusion when peripheral access was unfeasible, and subsequently, through a central venous catheter through the jugular, subclavian, or femoral vein, when necessary. A $0.9 \%$ saline solution was used as crystalloid therapy in all patients in the first two boluses, and human albumin in $5 \%$ saline solution or gelatin as colloid therapy in the third bolus in patients showing little improvement with the first two.

Vasoactive drugs used as inotropic agents included dobutamine (DBT) as a dopamine substitute, since it can be safely administered through a peripheral vein; catecholamines (epinephrine, $\mathrm{EPI}$; norepinephrine, norEPI); and vasodilators (nitroglycerin, NTG) and related drugs.

Variables The dependent variable was case fatality, defined as percentage of deaths at 28 days. Independent variables are described in Table 1. On arrival in PICU, all patients were assessed to determine whether they were in septic shock, and classified clinically by hemodynamic state (Table 1). Criteria for myocardial dysfunction or myocardial damage secondary to sepsis were corroborated by echo- and electrocardiography.

Data collection and analysis A form was designed to compile patient data during admission, to avoid having to refer to clinical history after patient discharge from PICU. SPSS 19.0 for Windows was used for data processing. Results were summarized in statistical tables with absolute and relative frequencies. Risk was estimated by calculating odds ratios (OR) with their 95\% confidence intervals, and statistical significance assessed with Fisher's exact test, with a threshold of $p<0.05$.

Ethics Written informed consent was obtained from the children's guardians, with assurance of patient anonymity. The study was approved by the HPU medical ethics committee.

\section{RESULTS}

In 2008-2010, patients with a diagnosis of septic shock accounted for $14.8 \%$ of PICU admissions (280/1894). A total of 31 patients died, for an overall 28-day case fatality rate of $11.1 \%$. Infants aged 1 month to 1 year were the largest age group diagnosed $(55 \%)$ but had the lowest case fatality, $7.1 \%$, and OR for death versus all other ages was $0.41(95 \% \mathrm{Cl}: 0.17-0.94, p=$
$0.02)$. There were more boys than girls diagnosed, $61.1 \%$ vs. $38.9 \%$, but girls had higher case fatality, $13.8 \%$ vs. $9.4 \%$ ( $p=$ 0.342) (Table 2).

Children with comorbidities were $16.1 \%$ of patients (45/280), but accounted for $45.2 \%$ of deaths (14/31), with case fatality of $31.1 \%$, vs. $7.2 \%(17 / 235)$ in previously healthy children. OR for death in children with comorbidities versus healthy children was 5.79 (95\% Cl: $2.42-13.88, \mathrm{p}<0.001)$. A breakdown of patients by age ( $<2$ years or $\geq 2$ years) showed that $33.3 \%$ (15/45) were in the group aged $<2$ years, with 4 deaths, for $26.7 \%$ case fatality (OR $3.21,95 \% \mathrm{Cl}: 0.80-11.9, \mathrm{p}=0.070)$; and $66.7 \%(30 / 45)$ in the group aged $\geq 2$ years, with 10 deaths, for $33.3 \%$ case fatality (OR 5.45, 95\% Cl: 2.07-14.3, p<0.001) (Table 2).

Most cases of sepsis (78.6\%) originated in the community, but case fatality was higher in cases of nosocomial origin $(23.3 \%$ vs. $7.7 \%, p=0.001)$ (Table 3).

Cold shock with low cardiac output (CO)/high systemic vascular resistance (SVR) was the most frequent hemodynamic state (68.9\%), followed by warm shock with high CO/low SVR $(18.6 \%)$. Cold shock with low CO/low SVR was less common (12.5\%), but had a higher case fatality, 34.3\% (OR 6.21, 95\% Cl: 2.47-15.57, p <0.001) (Table 3).

Glucose levels were tested in only 258 patients, with hyperglycemia found in 111 , or $43 \%$; there were 17 deaths in the hyperglycemic group, for a case fatality of $15.3 \%$ vs. $6.8 \%$ in patients with normal glucose levels (OR 2.48, 95\% Cl 1.02-6.12, $\mathrm{p}=0.04$ ). When hyperglycemia was in the $10-15.9 \mathrm{mmol} / \mathrm{L}$ range, case fatality was $25.6 \%$ (OR $3.55,95 \% \mathrm{Cl}: 1.08-12.04, p=0.03$ ); at higher glucose levels than this, very small numbers ( $n$ of 2 and 4) making significance testing moot (Table 4).

Apart from cardiovascular dysfunction-present in all patients by definition-respiratory (34\%) and hematologic (13.9\%) failure predominated. Sepsis-associated myocardial damage was found in $15.7 \%$ of patients (OR 5.1, 95\% Cl: 2.1-12.2, $p<0.001$ ). Case fatality increased with number of dysfunctional organs, up to $77.8 \%$ (7/9 patients) when 4 or more were involved (OR 36.02, 95\% Cl: 5.23-14.74, p <0.001) (Table 4).

Mechanical ventilation was used with $33.9 \%$ (95/280) of shock patients, with 29 deaths, for a $30.5 \%$ case fatality (OR $40.295 \%$ Cl 6.88-115.8, p <0.001). In 69.5\% (66/95) of those ventilated, the procedure was initiated within 30 minutes of admission, and in $81.1 \%$ within the first hour. Two patients were intubated but died before they could be connected to a ventilator. Some $33.7 \%$ of patients (32/95) were ventilated for $3-5$ days, and $29.5 \%(28 / 95)$ for $>10$ days (Table 4$)$.

In the first hour of treatment, $90 \%$ of patients (252/280) received fluid therapy, with volumes of $40-100 \mathrm{~mL} / \mathrm{kg}$. During this first hour, no patient received $>100 \mathrm{~mL} / \mathrm{kg}$ and 28 received $<40 \mathrm{~mL} / \mathrm{kg}$. In the first 3 hours, $96.4 \%$ of patients (270/280) received $40-100 \mathrm{~mL} / \mathrm{kg}$, $1.1 \%(3 / 280)$ received $>100 \mathrm{~mL} / \mathrm{kg}$, and $2.5 \%(7 / 280)$ received $<40 \mathrm{~mL} / \mathrm{kg}$. By six hours, $96.1 \%$ of patients $(269 / 280)$ had received $40-100 \mathrm{~mL} / \mathrm{kg}$ and $3.6 \%(10 / 280)>100 \mathrm{~mL} / \mathrm{kg}$; a single patient $(0.4 \%)$ received $<40 \mathrm{~mL} / \mathrm{kg}$. There were no complications of respiratory distress syndrome or cerebral edema secondary to fluid administration. 
Table 1: Independent variables

\section{Variables}

Age (group)

Sex

Comorbidities

Sepsis origin

Hemodynamic state

Glucose level (mmol/L)

\section{Description}

Per 2005 International Pediatric Sepsis Consensus Conference[18]

$<7$ days (newborn)

1 week to $<1$ month (neonate)

1 month-1 year (infant)

2-5 years (toddler and preschooler)

6-12 years (school age)

13-18 years (adolescent and young adult)

Male, female

Prior chronic clinical or surgical condition (e.g., oncohematologic or neurologic condition, congenital malformations)

Nominal qualitative variable with two categories:

- Community: acquired in the environment in which the patient lives and develops

- Nosocomial: acquired in any setting associated with medical care, primarily hospitals

Cold shock, late or hypodynamic

- Low CO and high SVR, suggested on physical exam by low tissue perfusion (evident in altered mental state), capillary refill $>2$ seconds, weak peripheral pulses compared to central pulses, cold mottled extremities, normal BP or low systolic BP with normal diastolic BP, with arterial clamping (e.g., $80 / 60 \mathrm{mmHg}$ )

- Low CO and low SVR, suggested on physical exam by low tissue perfusion, variable capillary refill, weak peripheral pulses, cold mottled extremities with low systolic and diastolic BP, the latter $<40 \mathrm{mmHg}$ or imperceptible

Warm shock, early and hyperdynamic

- High CO and low SVR, suggested on physical exam by altered mental state, flash capillary refill, warm extremities, bounding peripheral pulses, and low systolic BP and diastolic BP with a wide differential (e.g., $80 / 30 \mathrm{mmHg}$ )

Normal glucose level $\quad 4.4-6.6$

Hyperglycemia $\quad 6.7-9.9$

$10-15.9$

$16-20.0$

$>20$

Organ dysfunction

When, despite administration of intravenous isotonic fluid boluses of $\geq 40 \mathrm{~mL} / \mathrm{kg}$ in 1 hour, there is:

- A drop in BP (hypotension) to $<5$ percentile for age or systolic BP $>2$ SD below normal value for age

- Need for vasoactive drugs (dopamine $>5 \mu \mathrm{g} / \mathrm{kg} / \mathrm{min}$ or DBT, EPI, norEPI, at any dose) to maintain normal BP

Two of the following:

Cardiovascular $\quad$ - inexplicable metabolic acidosis: base deficit $>5.0 \mathrm{mEq} / \mathrm{L}$

- arterial lactate $>2$ times normal limit

- oliguria (urine output $<0.5 \mathrm{~mL} / \mathrm{kg} / \mathrm{h}$ )

- capillary refill delay ( $>5$ seconds)

- central-peripheral temperature difference $>30^{\circ} \mathrm{C}$

Respiratory

$\mathrm{PaO}_{2} / \mathrm{FiO}_{2}<300$ in absence of pre-existing cyanotic cardiopathy or pulmonary disease; or partial pressure of arterial carbon dioxide $\left(\mathrm{PaCO}_{2}>65\right.$ torr or $20 \mathrm{mmHg}>$ normal value of $\left.\mathrm{PaCO}_{2}\right)$; or need for $\mathrm{FiO}_{2}>50 \%$ to keep oxygen saturation at $\geq 92 \%$; or need for mechanical ventilation

Neurologic

Glasgow coma score $\leq 11$ points; or acute change in mental state with $\geq 3$-point drop in Glasgow coma score relative to normal baseline

Hematologic

Renal

Hepatic

Platelet count $<80,000 / \mathrm{mm}^{3}$ or $50 \%$ reduction relative to highest value recorded in previous 3 days (hematology and chronic oncology patients); or prothrombin time INR $>2$

Serum creatinine $\geq 2$ times normal limit for age or $>2$ SD relative to baseline

Total bilirubin $\geq 4 \mathrm{mg} / \mathrm{dL}$ (not applicable to newborns); or alanine aminotransferase $>2$ times upper limit of normal value for age

Mechanical ventilation

Fluid therapy administered

Yes: connected to mechanical ventilator

No: includes not-yet-connected and ventilated with self-inflatable bag

$<40 \mathrm{~mL} / \mathrm{kg}$ in first hour, first 3 hours or first 6 hours

$40-100 \mathrm{~mL} / \mathrm{kg}$ in first hour, first 3 hours or first 6 hours

$>100 \mathrm{~mL} / \mathrm{kg}$ in first hour, first 3 hours or first 6 hours

Fluid responsive (responsive to $>40 \mathrm{~mL} / \mathrm{kg}$ fluid replacement)

Fluid refractory-dopamine/DBT responsive

Fluid refractory-dopamine/DBT resistant, persisting after $\geq 60 \mathrm{~mL} / \mathrm{kg}$ of fluid resuscitation in the first hour and dopamine/

DBT infusion at $10 \mu \mathrm{g} / \mathrm{kg} / \mathrm{min}$

Therapeutic response

Fluid refractory-dopamine/DBT resistant, catecholamine responsive

Catecholamine resistant, persisting despite use of catecholamines, EPI or norEPI

Catecholamine resistant, vasodilator responsive

Refractory, persisting despite use of inotropic agents, vasopressors, vasodilators, and maintenance of both metabolic

(glucose and calcium) and hormonal (thyroid, hydrocortisone, and insulin) homeostasis

BP: blood pressure

EPI: Epinephrine

$\mathrm{PaCO}_{2}$ : partial pressure of arterial carbon dioxide
CO: cardiac output

norEPI: norepinephrine

$\mathrm{PO}_{2} / \mathrm{FiO}_{2}$ oxygen pressure/fraction of inspired oxygen
DBT: Dobutamine

NTG: nitroglycerin

SVR: systemic vascular resistance 


\section{Original Research}

Table 2: Population characteristics and comorbidities

\begin{tabular}{|c|c|c|c|c|c|c|}
\hline Variable & $\mathbf{n}$ & Deaths & $\begin{array}{c}\text { Case } \\
\text { fatality }\end{array}$ & OR & $95 \% \mathrm{Cl}$ & $\begin{array}{c}\mathbf{p} \\
\text { Value }\end{array}$ \\
\hline \multicolumn{7}{|l|}{ Sex } \\
\hline Male & 171 & 16 & 9.4 & & & \multirow{2}{*}{0.342} \\
\hline Female & 109 & 15 & 13.8 & 1.55 & $0.69-3.48$ & \\
\hline \multicolumn{7}{|l|}{ Age } \\
\hline$<1$ week & 21 & 3 & 14.3 & 1.38 & $0.30-5.39$ & 0.417 \\
\hline 1 week $-<1$ month & 30 & 3 & 10.0 & 0.88 & $0.20-3.32$ & 0.568 \\
\hline 1 month-1 year & 154 & 11 & 7.1 & 0.41 & $0.17-0.94$ & 0.020 \\
\hline $2-5$ years & 26 & 5 & 19.2 & 2.09 & $0.63-6.53$ & 0.144 \\
\hline $6-12$ years & 31 & 6 & 19.4 & 2.15 & $0.71-6.21$ & 0.109 \\
\hline $13-18$ years & 18 & 3 & 16.7 & 1.67 & $0.36-6.71$ & 0.319 \\
\hline Total & 280 & 31 & 11.1 & & & \\
\hline \multicolumn{7}{|c|}{ Comorbidities, by age (years) } \\
\hline$<2$ & 15 & 4 & 26.7 & $3.21^{a}$ & $0.80-11.9$ & 0.070 \\
\hline$\geq 2$ & 30 & 10 & 33.3 & $5.45^{a}$ & $2.07-14.3$ & $<0.001$ \\
\hline Total & 45 & 14 & 31.1 & $5.79^{b}$ & $2.42-13.9$ & $<0.001$ \\
\hline
\end{tabular}

${ }^{a}$ vs. all other children $\quad{ }^{b} v s$. healthy children, all ages

Table 3: 28-day case fatality by sepsis origin and shock hemodynamic type

\begin{tabular}{|c|c|c|c|c|c|c|}
\hline Variable & $\mathbf{n}$ & Deaths & $\begin{array}{c}\text { Case } \\
\text { fatality }\end{array}$ & OR & $95 \% \mathrm{Cl}$ & $\begin{array}{c}\mathbf{p} \\
\text { Value }\end{array}$ \\
\hline \multicolumn{7}{|l|}{ Sepsis origin } \\
\hline $\begin{array}{l}\text { Community } \\
\text { acquired }\end{array}$ & 220 & 17 & 7.7 & & & \\
\hline Nosocomial & 60 & 14 & 23.3 & 3.63 & $1.56-8.44$ & 0.001 \\
\hline \multicolumn{7}{|c|}{ Hemodynamic state } \\
\hline Low CO/high SVR & 193 & 10 & 5.2 & 0.17 & $0.07-0.41$ & $<0.001$ \\
\hline Low CO/low SVR & 35 & 12 & 34.3 & 6.21 & $2.47-15.6$ & $<0.001$ \\
\hline High CO/low SVR & 52 & 9 & 17.3 & 1.96 & $0.77-4.86$ & 0.179 \\
\hline
\end{tabular}

In combination drug therapy for cold shock (low CO/high SVR), the most frequently used drugs were DBT+EPI, the latter at a low dose of $0.05-0.3 \mu \mathrm{g} / \mathrm{kg} / \mathrm{min}$. In this same hemodynamic state, but with catecholamine-resistant, vasodilator-responsive shock, combinations of $\mathrm{EPI}+\mathrm{NTG}$ and $\mathrm{EPI}+\mathrm{NTG}+\mathrm{DBT}$ were used, this last in patients with associated severe myocardial damage. The most frequently used dose of EPI was $0.1-0.3 \mu \mathrm{g} / \mathrm{kg} / \mathrm{min}$ and of NTG, $5-7.5 \mu \mathrm{g} / \mathrm{kg} / \mathrm{min}$.

In cold shock (low CO/low SVR), the most frequent combination was DBT+norEPI, the latter at doses of $0.1-1.0 \mu \mathrm{g} / \mathrm{kg} / \mathrm{min}$; in only one patient was a dose higher than $1 \mu \mathrm{g} / \mathrm{kg} / \mathrm{min}$ used. The DBT+EPI combination was used in only 5 patients, the dose of the latter $>0.4 \mu \mathrm{g} / \mathrm{kg} / \mathrm{min}$. In warm shock, (high CO/low SVR), the most frequent combination was DBT+norEPI, dose of the latter $0.1-0.6 \mu \mathrm{g} / \mathrm{kg} / \mathrm{min}$; in only one patient the dose used was $1 \mu \mathrm{g} /$ $\mathrm{kg} / \mathrm{min}$ (Table 5).

The most common therapeutic response was fluid refractory, DBT responsive, 39.3\% (110/280), DBT being the vasoactive drug used as the main inotropic agent at $10 \mu \mathrm{g} / \mathrm{kg} /$ minute; the next most common response was fluid-refractory, DBT resistant, responsive to catecholamines in $26.4 \%$ (74/280). Although refractory shock constituted only $6.1 \%$ of cases $(17 / 280)$, it accounted for $54.8 \%$ of deaths $(17 / 31)$, with $100 \%$ case fatality (Table 5).
Table 4: Case fatality by glucose level, organ dysfunction and mechanical ventilation use

\begin{tabular}{|c|c|c|c|c|c|c|}
\hline Variable & $\mathbf{n}$ & Deaths & $\begin{array}{c}\text { Case } \\
\text { fatality }\end{array}$ & OR & $95 \% \mathrm{Cl}$ & $\begin{array}{c}\mathbf{p} \\
\text { Value }\end{array}$ \\
\hline \multicolumn{7}{|c|}{ Glucose level (mmol/L) } \\
\hline $6.7-9.9$ & 62 & 5 & 8.1 & 0.27 & $0.08-0.92$ & 0.033 \\
\hline $10-15.9$ & 43 & 11 & 25.6 & 3.55 & $1.08-12.0$ & 0.034 \\
\hline $16-20$ & 2 & 1 & 50.0 & & & \\
\hline$>20$ & 4 & 0 & 0.0 & & & \\
\hline \multicolumn{7}{|l|}{ Hyperglycemia } \\
\hline No & 147 & 10 & 6.8 & & & \\
\hline Yes & 111 & 17 & 15.3 & 2.48 & $1.02-6.12$ & 0.044 \\
\hline \multicolumn{7}{|l|}{ Organ failure } \\
\hline Respiratory & 95 & 29 & 30.5 & 40.2 & $6.9-115.8$ & $<0.001$ \\
\hline Hematologic & 39 & 17 & 43.6 & 12.5 & $5.1-31.4$ & $<0.001$ \\
\hline Neurologic & 11 & 6 & 54.5 & 11.7 & $3.5-11.3$ & $<0.001$ \\
\hline Renal & 8 & 5 & 62.5 & 15.8 & $3.4-12.5$ & $<0.001$ \\
\hline Hepatic & 3 & 2 & 66.7 & 17.1 & $2.7-15.2$ & 0.033 \\
\hline $\begin{array}{l}\text { Myocardial } \\
\text { damage second- } \\
\text { ary to sepsis }\end{array}$ & 44 & 13 & 29.5 & 5.1 & $2.1-12.2$ & $<0.001$ \\
\hline \multicolumn{7}{|c|}{ Number of organs in failure } \\
\hline 1 & 179 & 2 & 1.1 & 0.03 & $0.01-0.16$ & $<0.001$ \\
\hline 2 & 60 & 10 & 16.7 & 1.90 & $0.87-3.51$ & 0.184 \\
\hline 3 & 32 & 12 & 37.5 & 7.23 & $2.63-9.12$ & $<0.001$ \\
\hline$\geq 4$ & 9 & 7 & 77.8 & 36.0 & $5.23-14.7$ & $<0.001$ \\
\hline \multicolumn{7}{|c|}{ Mechanical ventilation } \\
\hline No & 185 & 2 & 1.1 & & & \\
\hline Yes & 95 & 29 & 30.5 & 40.2 & $6.9-115.8$ & $<0.001$ \\
\hline \multicolumn{7}{|l|}{ Start (min) } \\
\hline$<30$ & 66 & 20 & 30.3 & 0.97 & $0.34-2.77$ & 0.864 \\
\hline $30-60$ & 11 & 4 & 36.4 & 1.35 & $0.52-2.85$ & 0.446 \\
\hline$>60$ & 18 & 5 & 27.8 & 0.85 & $0.39-2.01$ & 0.997 \\
\hline \multicolumn{7}{|l|}{ Duration (days) } \\
\hline$<3$ & 19 & 10 & 52.6 & 3.33 & $1.18-3.75$ & 0.039 \\
\hline $3-5$ & 32 & 5 & 15.6 & 0.30 & $0.09-0.97$ & 0.044 \\
\hline $6-10$ & 16 & 2 & 12.5 & 0.28 & $0.04-1.42$ & 0.072 \\
\hline$>10$ & 28 & 12 & 42.9 & 2.21 & $0.79-6.19$ & 0.093 \\
\hline
\end{tabular}

A total of 14 patients recovered from septic shock but died of other causes before 28 days. Of these, 11 suffered from chronic conditions or comorbidities (OR 6.5, 95\% Cl 2.69-15.7, p <0.001). Of the same 14, 12 developed organ dysfunction secondary to sepsis; 10 had comorbidities, including hematologic cancer (5), infantile cerebral palsy (3), and high-risk congenital malformations in newborns (2); 2 without comorbidities had central nervous system infections. There were two deaths from accidents during emergency medical care (central venous catheterization and tracheostomy decannulation).

\section{DISCUSSION}

The 28-day case fatality rates we observed are within the range found in other hospitals that have similarly applied ACCM Guidelines.[14] The Han study reports an association between early use of ACCM Pediatric Advanced Life Support Guidelines and improved outcomes in newborns and children (case fatality $38 \%$ without vs. $8 \%$ with).[19] Menif reports a similar experience with optimal management of critical shock patients within the first hour, 
Table 5: Case fatality by therapeutic response and drugs utilized

\begin{tabular}{|c|c|c|c|c|c|c|c|}
\hline \multicolumn{2}{|c|}{ Therapeutic response classification } & $\mathbf{n}$ & Deaths & $\begin{array}{l}\text { Case } \\
\text { fatality }\end{array}$ & OR & $95 \% \mathrm{Cl}$ & $\begin{array}{c}\mathbf{p} \\
\text { Value }\end{array}$ \\
\hline \multicolumn{2}{|l|}{ Fluid responsive } & 57 & 0 & 0.0 & & & \\
\hline \multicolumn{2}{|c|}{ Fluid refractory, DBT responsive } & 110 & 4 & 3.6 & 0.20 & $0.06-0.62$ & 0.002 \\
\hline \multicolumn{2}{|c|}{$\begin{array}{l}\text { Fluid refractory, DBT resistant, } \\
\text { catecholamine responsive }\end{array}$} & 74 & 9 & 12.2 & 1.16 & $0.47-2.61$ & 0.727 \\
\hline \multicolumn{2}{|c|}{$\begin{array}{l}\text { Catecholamine resistant, } \\
\text { vasodilator responsive }\end{array}$} & 22 & 1 & 4.5 & 0.21 & $0.01-2.4$ & 0.172 \\
\hline \multicolumn{2}{|l|}{ Refractory } & 17 & 17 & 100.0 & & & \\
\hline \multicolumn{8}{|c|}{ Drugs utilized by hemodynamic state } \\
\hline \multirow{3}{*}{ Low CO/high SVR } & $\mathrm{DBT}+\mathrm{EPI}$ & 22 & 4 & 18.2 & 1.41 & $0.22-9.48$ & 0.500 \\
\hline & $\mathrm{EPI}+\mathrm{NTG}$ & 11 & 1 & 9.1 & 0.45 & $0.02-4.80$ & 0.429 \\
\hline & $\mathrm{DBT}+\mathrm{EPI}+\mathrm{NTG}$ & 11 & 0 & 0.0 & & & \\
\hline \multirow{2}{*}{ Low CO/low SVR } & $\mathrm{DBT}+\mathrm{EPI}$ & 5 & 1 & 20.0 & 0.36 & $0.08-3.00$ & 0.626 \\
\hline & $\mathrm{DBT}+$ norEPI & 27 & 11 & 40.7 & 2.04 & $0.33-12.46$ & 0.365 \\
\hline \multirow{2}{*}{ High CO/low SVR } & $\mathrm{DBT}+\mathrm{EPI}$ & 1 & 1 & 100.0 & & & \\
\hline & $\mathrm{DBT}+$ norEPI & 31 & 4 & 12.9 & 0.13 & $0.05-0.32$ & 0.156 \\
\hline $\begin{array}{l}\text { O: cardiac output } \\
\text { IorEPI: norepinephrine }\end{array}$ & $\begin{array}{l}\text { DBT: } d \\
\text { NTG: } r\end{array}$ & & & & & e & istance \\
\hline
\end{tabular}

$36.9 \%$ ) and $49 \%$ nosocomial (case fatality of 42.5\%).[26] On the other hand, a multicenter study of adults in Germany (2075 ICUs in 1380 hospitals) found that only $39.1 \%$ of sepsis was community acquired, while $46.7 \%$ was nosocomial $(32.9 \%$ in ICUs, $13.8 \%$ in other services, $14.2 \%$ in undetermined locations).[27]

As Ceneviva points out, once treatment for shock has begun, septic hemodynamic states can progress and change, especially in the first 48 hours; he reports on 50 children with dopamine-resistant $(\geq 60 \mathrm{~mL} / \mathrm{kg}$ in the first hour) fluid-refractory shock, most of whom $(58 \%)$ had cold shock with low CO/high SVR; $22 \%$ had low CO/low SVR; and only $18 \%$ had warm shock with high CO/low SVR. These figures are similar to ours, in which cold shock with low CO/high SVR also predominated.[28]

Furnary and Braithwaite note that hyperglycemia is frequently observed in gravely ill

noting that each hour that passes without restoring normal (for age) blood pressure and capillary refill to less than three seconds is associated with a twofold increase in case fatality.[20] The Sophia Children's Hospital in Rotterdam recently reported a substantial reduction in case fatailty from purpura and severe sepsis after implementation of $\mathbf{2 0 0 2}$ guideline-based therapy in the referral center, transport system, and tertiary care settings.[21] This center also used high flux continuous renal replacement therapy and fresh frozen plasma infusion aimed at achieving normal prothrombin time (international normalized ratio)

The statistically significant predominance of infants versus other age groups is common, and can be explained by their immunologic immaturity.[22] The male:female ratio observed (1.6:1) was slightly higher than reported in a Brazilian hospital (1.3:1, with $56.1 \%$ of sepsis in males) and lower than reported in Panama City (male:female ratio of 2:1, with $67 \%$ of sepsis in males).[23]

Our observed case fatality for patients with chronic conditions was higher than reported for some international institutions that followed the 2007 Guidelines (7\%-10\%).[16,24] In the most important epidemiological study of pediatric sepsis, Watson reviewed the discharge databases of 942 hospitals in the USA and found higher case fatality in patients with severe sepsis who had comorbidities, from $14.2 \%$ in children aged $10-19$ years to $58.7 \%$ in aged 1-9 years, but provided no analysis of Guideline compliance. The higher rates in the latter could be explained by greater proportions of children with comorbidities from conditions such as cancer, congenital birth defects, cerebral palsy and end-stage renal disease.[25]

In our study, community-acquired infection predominated, which is not surprising, given the higher proportion of previously healthy people in the general population; however, a higher risk of death was associated with nosocomial sepsis, owing to the aggressiveness and more powerful resistance mechanisms of hospital microorganisms. In his retrospective study (1981-1992) of children with sepsis in a Panama City hospital, Sáez-Llorens found that $60 \%$ of infections were community acquired (case fatality of patients; it has many causes, but is most often associated with metabolic stress.[29]

Sepsis is characterized by marked insulin resistance, directly proportional to severity of stress response. In 2004, the Surviving Sepsis Campaign recommended glucose monitoring for all patients with sepsis.[30] This recommendation was retained in the 2008 and 2013 updates[31,32] and has led to worldwide adoption of strict glucose monitoring in ICUs.

Brierley notes that children in septic shock with hyperglycemia of $>140 \mathrm{mg} / \mathrm{dL}$ and an elevated anion gap exhibit resolution of this gap when insulin is added to their regimen, observing a reduction in catabolism.[16] In a similar study of pediatric patients in septic shock, Branco shows outcomes that coincide with ours, reporting an increase in the risk of death with glycemia $>9.9 \mathrm{mmol} / \mathrm{L}$.[33] In another prospective observational study of children with meningococcal septic shock, Verhoeven found hyperglycemia of $>8.3$ $\mathrm{mmol} / \mathrm{L}$ in $33 \%$ of patients.[34]

There are few studies of organ dysfunction in children; in a retrospective study (1990-1995), Mora found that the syndrome is common and case fatality very high, with a risk of death of $25 \%-52 \%$ in children with severe sepsis and septic shock. This figure is compatible with our findings.[35] In a Lima, Peru PICU, Tantalean found that case fatality increased in direct proportion to number of organs in failure, from $29.4 \%$ for 2 organs to $100 \%$ for $\geq 5$.[36] In a prospective study in a Malaysian PICU, Goh found a case fatality rate of $57 \%$ for patients admitted with any organ failure, compared with $0.5 \%$ in patients without organ dysfunction. Case fatality increased directly with the number of organs in failure (from $44 \%$ for 2 organs to $92 \%$ for $\geq 4$ ). [37]

Brierley cites several reasons for starting mechanical ventilation early in patients with septic shock, since up to $40 \%$ of cardiac output may be required to support respiration, and sedation and analgesia combined with ventilation facilitate temperature control and reduce oxygen consumption.[16] Therefore, any 


\section{Original Research}

patient not reaching rapid stabilization with peripherally administered fluids and inotropic agents should be put on mechanical ventilation. Less commonly, mechanical ventilation is required for patients with respiratory failure, deteriorating mental state, or in extremely critical condition. These criteria are consistent with those utilized in this study; patients requiring this treatment were at high risk of death, as the outcomes indicate.

It was not until 1998 that researchers reported outcomes of using aggressive volume resuscitation in children with septic shock $(60 \mathrm{~mL} / \mathrm{kg}$ of fluid in the first hour), with the therapeutic goal of obtaining a cardiac index of 3.3-6.0 L/min $/ \mathrm{m}^{2}$ and normal pressure in the pulmonary capillary bed.[38] Since 2002, several randomized studies of patients with dengue shock syndrome,[39] WHO grade III (narrow pulse pressure/tachycardia) and some with grade IV (hypotension), who received aggressive fluid resuscitation have observed a survival rate of nearly $100 \%$, regardless of fluid used.

In our study, similar fluid volumes were aggressively administered without complications, a result also observed by Brierley, who reports that none of the children who were administered large fluid volumes to stabilize them developed respiratory distress syndrome or cerebral edema.[16]

These outcomes differ from those of Maitland, who reports that after boluses of fluid were administered to African children with severe infections, there was a $2-3 \%$ increase in pulmonary edema and intracranial pressure, with a slight but statistically insignificant increase in relative risk. It should be noted that $>55 \%$ of these patients had malaria, a disease commonly associated with neurologic and pulmonary complications.[40]

Chopra's randomized study compared the efficacy of $3 \%$ saline solution and $0.9 \%$ solution in initial fluid resuscitation therapy administered to 60 children aged $2-12$ years with septic shock. The amount of fluid required for resuscitation with $3 \%$ saline solution was roughly half that required with $0.9 \%$ solution, but use of vasopressors, time taken to resolve shock, length of stay, and PICU case fatality were similar in both groups, leading to the conclusion that the two fluids are equally effective in restoring hemodynamic stability and maintaining average length of stay in PICU, with similar case fatality rates.[41] In our study, the only crystalloid fluid used was $0.9 \%$ saline solution, with satisfactory outcomes.

Among vasoactive drugs, dopamine/DBT (5-9 $\mu \mathrm{g} / \mathrm{kg} / \mathrm{min})$ or EPI $(0.05-0.3 \mu \mathrm{g} / \mathrm{kg} / \mathrm{min})$ can be used as first-line inotropic support, DBT especially in cases of low CO with adequate or increased SVR.[22] Kissoon states that inotropic agents should be administered via peripheral venous or intraosseous access when central venous access is unavailable, because delayed administration of inotropic agents can substantially increase risk of death.[42] These criteria were employed in our study, using DBT as the main inotropic agent because it can be administered through a peripheral vein, given difficulties with venous access in children, especially newborns and infants.

In managing children with normal blood pressure in fluid-refractory dopamine/DBT-resistant cold shock and low
CO/high SVR, use of an inotropic agent like EPI that lowers SVR is recommended, along with a fast-acting vasodilator such as sodium nitroprusside or NTG, to restore microcirculation and reduce afterload; this results in improved ventricular ejection and overall cardiac output, particularly when ventricular function is compromised,[43-46] a criterion also used in this study. Sakr notes that even though dopamine is still considered the first-line vasopressor for fluid-refractory hypotensive shock and low SVR, there is evidence that patients treated with this drug have poorer outcomes.[47] Liet has also noted that dopamine resistance is common in infancy; sympathetic innervation in immature animals and young humans (newborns, preterm infants, and infants $<6$ months) may not have fully developed, resulting in reduced norEPI release from their reserves.[48]

Dopamine-resistant shock commonly responds to norEPI or high doses of EPI.[29] Dopamine was not used as a vasopressor in this study; this effect was obtained with early use of norEPI, although at low doses, for fluid-refractory hypotensive hyperdynamic shock, as recommended by Morimatsu. [49] Hall recommends use of DBT with norEPI, noting that it is a potent inotropic agent with intrinsic vasodilating action that can be useful in counteracting norEPI's excessive vasoconstriction.[50]

Improved capillary and intestinal blood flow have been observed in animal and human studies with norEPI plus DBT in comparison with high doses of dopamine or EPI.[51] The drug combinations used in our study follow the criteria indicated by these authors.[49-51]

Our results suggest that implementation of ACCM Guidelines to achieve early diagnosis and swift initiation of goal-directed therapy has contributed to lowering case fatality from septic shock in HPU's PICU, which fell from $34.6 \%$ in 2003 to $19 \%$ in 2007 (administrative data), and to $11.1 \%$ in the 3-year period of this study. Examples of actions taken within these Guidelines are optimal management in the first hour, early and aggressive fluid resuscitation, support with vasoactive drugs singly or in combination, early use of mechanical ventilation as necessary, and insulin therapy to maintain normal blood glucose levels. $[9,16,20]$

The main limitations of this study are its ecological design and short duration, which did not permit research on case fatality over a longer period or confirmation of how implementing ACCM Guidelines affected the downward trend. However, the experience gained has been critical for saving the lives of young patients. Another equally important limitation is the lack of patient assessment using pediatric scores that predict death and organ dysfunction (PRISM, PELOD).[51,52]

\section{CONCLUSIONS}

The ACCM Guidelines are a valuable instrument for timely, appropriate care of pediatric patients in septic shock: early aggressive fluid therapy, supported by vasoactive drugs singly and in combination, can have a positive impact on clinical course. Multicenter studies with larger numbers of patients are needed to corroborate these observations and further improve management of pediatric shock. Wh 


\section{REFERENCES}

1. Watson RS, Carcillo JA. Scope and Epidemiology of Pediatric Sepsis. Pediatr Crit Care Med. 2005 May;6(3 Suppl):S3-5.

2. Aneja R, Carcillo J. Differences between adult and pediatric septic shock. Minerva Anestesiol. 2011 Oct;77(10):986-92.

3. Standage SW, Wong HR. Biomarkers for pediatric sepsis and septic shock. Expert Rev Anti Infect Ther. 2011 Jan;9(1):71-9.

4. Wong HR. Genetics and genomics in pediatric septic shock. Crit Care Med. 2012 May;40(5):1618-26.

5. Wong HR. Clinical review: sepsis and septic shock-the potential of gene arrays. Crit Care. 2012 Feb 8;16(1):204.

6. Wong HR, Cvijanovich NZ, Allen GL, Thomas $\mathrm{NJ}$, Freishtat RJ, Anas N, et al. Validation of a gene expression-based subclassification strategy for pediatric septic shock. Crit Care Med. 2011 Nov;39(11):2511-7.

7. Phumeetham S, Chat-Uthai N, Manavathongchai M, Viprakasit V. Genetic association study of tumor necrosis factor-alpha with sepsis and septic shock in Thai pediatric patients. J Pediatr (Rio J). 2012 Sep-Oct;88(5):417-22. English, Portuguese.

8. Larsen GY, Mecham N, Greenberg R. An emergency department septic shock protocol and care guideline for children initiated at triage. Pediatrics. 2011 Jun;127(6):e1585-92.

9. Carcillo JA, Fields Al; American College of Critical Care Medicine Task Force Committee Members. Clinical practice parameters for hemodynamic support of pediatric and neonatal patients in septic shock. Crit Care Med. 2002 Jun;30(6):1365-78.

10. de Oliveira CF. Early goal-directed therapy in treatment of pediatric septic shock. Shock. 2010 Sep;34 Suppl 1:44-7.

11. Aneja RK, Varughese-Aneja R, Vetterly CG, Carcillo JA. Antibiotic therapy in neonatal and pediatric septic shock. Curr Infect Dis Rep. 2011 Oct;13(5):433-41.

12. Angus DC, Linde-Zwirble WT, Lidicker J, Clermont G, Carcillo J, Pinsky MR. Epidemiology of severe sepsis in the United States: analysis of incidence, outcome, and associated costs of care. Crit Care Med. 2001 Jul;29(7):1303-10.

13. Ngo NT, Cao XT, Kneen R, Willis B, Nguyen $V M$, Nguyen TQ, et al. Acute management of dengue shock syndrome: a randomized doubleblind comparison of 4 intravenous fluid regimens in the first hour. Clin Infect Dis. 2001 Jan 15;32(2):204-13.

14. Kutko MC, Calarco MP, Flaherty MB, Helmrich RF, Ushay HM, Pon S, et al. Mortality rates in pediatric septic shock with and without multiple organ failure. Pediatr Crit Care Med. 2003 Jul;4(3):333-7.

15. González A, Valdés F, Fernández F, Ardisana $O$, Álvarez Al, Francisco JC. Comportamiento de la sepsis en terapia intensiva pediátrica. Rev Cub Med Int Emerg [Internet]. 2007 Sep [cited 2013 Sep 28];6(3):857-70. Available from: http://bvs.sld.cu/ revistas/mie/vol6_3_07/mie08307.htm. Spanish.

16. Brierley J, Carcillo JA, Choong K, Cornell T, Decaen A, Deymann A, et al. Clinical practice parameters for hemodynamic support of pediatric and neonatal septic shock: 2007 update from the American College of Critical Care Medicine. Crit Care Med. 2009 Feb;37(2):666-88.

17. Levy MM, Fink MP, Marshall JC, Abraham E, Angus D, Cook D, et al. 2001 SCCM/ESICM/ ACCP/ATS/SIS (2001) International Sepsis Definitions Conference. Crit Care Med. 2003 Apr;31(4):1250-6.

18. Goldstein B, Giroir B, Randolph A; International Consensus Conference on Pediatric Sepsis.
International pediatrics sepsis consensus conference: definition for sepsis and organ dysfunction in pediatrics. Pediatric Crit Care Med. 2005 Jan;6(1):2-8.

19. Han YY, Carcillo JA, Dragotta MA, Bills DM, Watson RS, Westerman ME, et al. Early reversal of pediatric septic shock by community physicians is associated with improved outcome. Pediatrics. 2003 Oct;112(4):793-9.

20. Menif K, Bouziri A, Ben Jaballah N. [Management of the first hour of the pediatric septic shock patient]. Tunis Med. 2011 Feb;89(2):1325. French.

21. Maat $M$, Buysse $C M$, Emonts $M$, Spanjaard $\mathrm{L}$, Joosten KF, de Groot $\mathrm{R}$, et al. Improved survival in children with sepsis and purpura: effects of age, gender, and era. Crit Care. 2007;11(5):R112.

22. Noguera L. Morbimortalidad por sepsis en niños gravemente enfermos. Med Crit Ter Intens. 2005;16(1):5-11. Spanish

23. Jaramillo JC, Marín A, Fernández M, Bareño J. Epidemiología de la sepsis en pediatría: primer Estudio Colombiano Multicéntrico. Rev CES Med. 2009;23(1):85-92. Spanish.

24. Odetola FO, Gebremariam A, Freed GL. Patient and hospital correlates of clinical outcomes and resource utilization in severe pediatric sepsis. Pediatrics. 2007 Mar;119(3):487-94.

25. Watson RS, Carcillo JA, Linde-Zwirble WT, Clermont G, Liddicker J, Angus DC. The epidemiology of severe sepsis in children in the United States. Am J Respir Crit Care Med. 2003 Mar 1;167(5):695-701.

26. Sáez-Lloréns X, Vargas S, Guerra F, Coronado L. Application of new sepsis definitions to evaluate outcome of pediatric patients with severe systemic infections. Pediatr Infect Dis J. 1995 Jul;14(7):557-61.

27. Engel C, Brunkhorst FM, Bone HG, Brunkhorst R, Gerlach H, Grond S, et al. Epidemiology of sepsis in Germany: results from a national prospective multicenter study. Intensive Care Med. 2007 Apr;33(4):606-18.

28. Ceneviva G, Paschall JA, Maffei F, Carcillo JA. Hemodynamic support in fluid refractory pediatric septic shock. Pediatrics. 1998 Aug;102(2):e19.

29. Furnary AP, Braithwaite SS. Effects of outcome on in-hospital transition from intravenous insulin infusion to subcutaneous therapy. Am J Cardiol. 2006 Aug 15;98(4):557-64.

30. Dellinger RP, Carlet JM, Masur H, Gerlach H, Calandra T, Cohen J, et al. Surviving Sepsis Campaign guidelines for management of severe sepsis and septic shock. Crit Care Med. 2004 Mar;32(3):858-73.

31. Dellinger R, Levy MM, Carlet JM, Bion J, Parker MM, Jaeschke R, et al. Surviving Sepsis Campaign: International guidelines for management of severe sepsis and septic shock: 2008. Intensive Care Med. 2008 Jan;34(1):17-60.

32. Dellinger R, Levy MM, Rhodes A, Annane D, Gerlach H, Opal SM, et al. Surviving Sepsis Campaign: International Guidelines for Management of Severe Sepsis and Septic Shock. Crit Care Med. 2013 Feb;41(2):580-637.

33. Branco RG, Garcia PC, Piva JP, Casartelli CH, Seibel V, Tasker RC. Glucose level and risk of mortality in pediatric septic shock. Pediatric Crit Care Med. 2005 Jul;6(4):470-2.

34. Verhoeven JJ, den Brinker M, Hokken-Koelega AC, Hazelzet JA, Joosten KF. Pathophysiological aspects of hyperglycemia in children with meningococcal sepsis and septic shock: a prospective, observational cohort study. Crit Care. 2011;15(1):R44.
35. Mora E, Casado J, García J, González N, Monleón M, Serrano A. Multiorgan dysfunction in children: A review of 173 cases. Intensive Care Med. 1996;22:S168

36. Tantaleán JA, León RJ, Santos AA, Sánchez E. Multiple organ dysfunction syndrome in children. Pediatr Crit Care Med. 2003 Apr;4(2):181-5.

37. Goh A, Lum L. Sepsis, severe sepsis and septic shock in paediatric multiple organ dysfunction syndrome. J Paediatr Child Health.1999 Oct;35(5):488-92.

38. Stoner MJ, Goodman DG, Cohen DM, Fernandez SA, Hall MW. Rapid fluid resuscitation in pediatrics: testing the American College of Critical Care Medicine guideline. Ann Emerg Med. 2007 Nov;50(5):601-7.

39. Wills BA, Nguyen MD, Ha TL, Dong TH, Tran TN Le TT, et al. Comparison of the three fluid solutions for resuscitation in dengue shock syndrome. N Engl J Med. 2005 Sep 1;353(9):877-89.

40. Maitland K, Kiguli S, Opoka RO, Engoru C, Olupot-Olupot $\mathrm{P}$, Akech SO, et al. Mortality after fluid bolus in African children with severe infection. N Engl J Med. 2011 Jun 30;364(26):2483-95.

41. Chopra A, Kumar V, Dutta A. Hypertonic versus normal saline as initial fluid bolus in pediatric septic shock. Indian J Pediatr. 2011 Jul;78(7):833-7.

42. Kissoon N, Orr RA, Carcillo JA. Updated American College of Critical Care Medicine--pediatric advanced life support guidelines for management of pediatric and neonatal septic shock: relevance to the emergency care clinician. Pediatr Emerg Care. 2010 Nov;26(11):867-9.

43. Ruza F, García S, Muñoz Jl. Terapéutica hemodinámica. In: Ruza F, editor. Cuidados Intensivos Pediátricos. 3rd ed, Vol. 1. Madrid: Editorial Norma Capitel; 2003. Chapter 19. Spanish.

44. Laitinen P, Happonen JM, Sairanen H, Peltola $\mathrm{K}$, Rautiainen P, Korpela R, et al. Amrinone vs dopamine-nitroglycerin after reconstructive surgery for complete atrioventricular septal defect. J Cardiothorac Vasc Anesth. 1997 Dec;11(7):870-4.

45. Jain P, Bansal A. Epinephrine in pediatric septic shock: does the algorithm speak what the recommendations say? Crit Care Med. 2010 Apr;38(4):1237-8

46. Montalván GL. Epinefrina en el estado de choque séptico en pediatría: a propósito de un debate. Rev Cubana Pediatr [Internet]. 2010 Sep [cited 2013 Sep 28];82(3):89-91. Available from: http://scielo.sld.cu/scielo.php ?script=sci_arttext\&pid=S0034-75312010000 300011\&Ing=es. Spanish.

47. Sakr Y, Reinhart K, Vincent JL, Sprung CL, Moreno R, Ranieri VM, et al. Does dopamine administration in shock influence outcome? Results of the Sepsis Occurrence in Acutely III Patients (SOAP) Study. Crit Care Med. 2006 Mar;34(3):589-97.

48. Liet JM, Boscher C, Gras-Leguen C, Gournay V, Debillon T, Rozé JC. Dopamine effects on pulmonary artery pressure in hypotensive preterm infants with patent ductus arteriosus. J Pediatr. 2002 Mar;140(3):373-5

49. Morimatsu $H$, Singh $K$, Uchino $S$, Bellomo R, Hart G. Early and exclusive use of norepinephrine in septic shock. Resuscitation. 2004 Aug;62(2):249-54

50. Hall LG, Oyen LJ, Taner CB, Cullinane DC, Baird TK, Cha SS, et al. Fixed-dose vasopressin compared with titrated dopamine and norepinephrine as initial vasopressor therapy for septic shock. Pharmacother. 2004 Aug;24(8):1002-12.

51. Pollack MM, Patel KM, Ruttimann UE. PRISM III: An updated Pediatric Risk of Mortality Score. Crit Care Med. 1996 May:24(5):743-52. 
52. Leteurte S, Martinot A, Duhamel A, Proulx F, Grandbastien B, Cotting J, et al. Validation of the paediatric logistic organ dysfunction (PELOD) score: Prospective, observational, multicentre study. Lancet. 2003 Jul 19;362(9379):192-7.

\section{THE AUTHORS}

José Manuel Cartaya Yrastorza (Corresponding author: cartaya@hped.vcl.sld. cu, cartayajm@gmail.com), pediatrician and emergency medicine specialist, with master's degrees in hospital administration and primary care emergency medicine. Associate professor, Medical University of Villa Clara (UCMVC) and José Luis Miranda Pediatric University Hospital (HPU), Santa Clara, Cuba.
Luis Enrique Rovira Rivero, family physician and pediatrician with a master's degree in primary care emergency medicine. Instructor at UCMVC and HPU, Santa Clara, Cuba.

Yamilet Segredo Molina, family physician and specialist in intensive care and emergency medicine, with a master's degree in primary care emergency medicine. Assistant professor, UCMVC and HPU, Santa Clara, Cuba.

Idalys Álvarez González, family physician and pediatrician with a diploma in pediatric intensive care. Instructor, HPU, Santa Clara, Cuba.

Yoandra Acevedo Rodríguez, family physician and specialist in intensive care and emergency medicine. Instructor, UCMVC and HPU, Santa Clara, Cuba.

Ariel Moya Machado, pediatrician with a master's degree in infectious disease. Assistant professor, UCMVC and HPU, Santa Clara, Cuba.

Submitted: September 24, 2012

Approved for publication: June 14, 2014 Disclosures: None

\section{ERRATA}

Orantes CM, Herrera R, Almaguer M, Bayarre H, Orellana P, Brizuela EG, et al. Epidemiology of Chronic Kidney Disease in Adults of Salvadoran Agricultural Communities. MEDICC Rev. 2014 Apr;16(2):23-30.

Page 25, Table 1, units of measurement for albuminuria are mg albumin per $\mathrm{g}$ creatinine.

Page 26, first complete paragraph, the last line should read, "Most CKD patients

(51.9\%) had no DM, HT or proteinuria."

VanDervort DR, López DL, Orantes CM, Rodríguez DS. Spatial Distribution of Unspecified chronic kidney disease in El Salvador by Crop Area cultivated and ambient temperature. MEDICC Rev. 2014 Apr;16(2):31-8.

Page 31, Abstract, Methods, fifth line, rates are per thousand population.

Page 32, second paragraph of Methods, third line, rates are per thousand population.

Page 34, Table 1, legend ptp should be per thousand population.

Page 35, Figure 1, legend b should read, municipal rates/1000 population 2006-10; labels a, b, c and d should be removed from maps. 